\title{
MALAYSIAN ENERGY DEMAND AND EMISSIONS FROM THE TRANSPORTATION SECTOR
}

\author{
Anwar Al-Mofleh ${ }^{1}$, Soib Taib ${ }^{2}$, Wael A. Salah ${ }^{3}$ \\ 1, 2, ${ }^{3}$ School of Electrical and Electronics Engineering, Engineering Campus, Universiti Sains Malaysia, \\ 14300 Nibong Tebal, Pulau Pinang, Malaysia \\ ${ }^{1}$ Faculty of Engineering Technology, Al-Balqa' Applied University, Marka Ashamalia, Amman, Jordan \\ E-mails: ${ }^{1}$ anwaralmofleh@yahoo.com; ${ }^{2}$ soibtaib@eng.usm.my; ${ }^{3}$ wael_sal@yahoo.com
}

Received 18 February 2010; accepted 15 November 2010

\begin{abstract}
Road transport represents one of the greatest areas of challenge for energy efficiency. A growing percentage of petrol usage is due to consumption in the transportation sector. However, in other sectors, petrol has been recently partially or totally substituted by other fuels. The need for worldwide action to achieve energy efficiency in the transportation sector has been recognized by the agencies of the United Nations and other international governmental and non-governmental organizations. Transportation is one of the key factors for the growth and development of Malaysian economy. Currently, more than $80 \%$ of primary energy consumption based on fossil fuels and demand stays high and is supposed continually grow in the future. Even if technology developments eventually able to reduce specific consumption, world energy demand is likely to increase in line with its population. This sector also accounts for a substantial amount of air pollution in cities and contributes significantly to greenhouse gas emissions. This paper aims to analyze factors influencing the pattern and emission level of energy consumption in the transportation sector of Malaysia and extrapolates the total energy demand and vehicular emissions.
\end{abstract}

Keywords: energy efficiency, transportation policy, gas emissions.

\section{Introduction}

Transportation is one of the main human activities around the world. Similar actions burn limited nonrenewable energy that leads to some negative impact on our living environment. It seems to be necessary to adopt a suitable energy policy for the transportation sector as one of the options to balance demand and supply for energy at the government, society and individual levels (National Energy Balance 2005). Energy planning and policy have become very important in the public agenda of the most developed countries today. The importance of energy planning and policy is linked to industrial competitiveness, energy security and environmental advantage (The Malaysian Economic... 2004). Transportation in Malaysia is still using traditional fossil fuel types such as gasoline, diesel and electricity. These activities generate millions of tons of greenhouse gases each year. The pattern of emission production by the transportation sector in Malaysia has not been analysed accurately yet (Malaysia Initial... 2000). Suitable energy planning and policy in the transportation sector can reduce demand for fossil fuel and hence decrease the production of greenhouse gases and other emissions.
Based on fossil fuel consumption, transportation sector accounts for almost $49 \%$ of the national greenhouse gas emissions (National Energy Balance 2003). Energy conservation in the transport sectors helps with reducing energy consumption. In most countries, transportation energy consumption ranges from $20 \%$ to $60 \%$ of the total electricity consumption.

The transportation sector in Malaysia uses about $40 \%$ of the total energy demand (The Malaysian Economic... 2004). Energy use by sector in Malaysia is presented in Fig. 1 (National Energy Balance 2003). This energy is used by various types of transport (motor car, motorcycle, bus, goods vehicle, train, LRT, airplane, marine etc.) to provide transportation services and other end-uses for society.

Ideally, fuel consumption of different vehicles such as a motor car, motorcycle, bus or freight vehicle must be set to a certain level in order to ensure that they use energy efficiently (National Energy Balance 2005).

The effective use of energy and caring about the environment are two important conducive factors under the current global market conditions realizing that the policy of energy efficiency is becoming a strategic poli- 


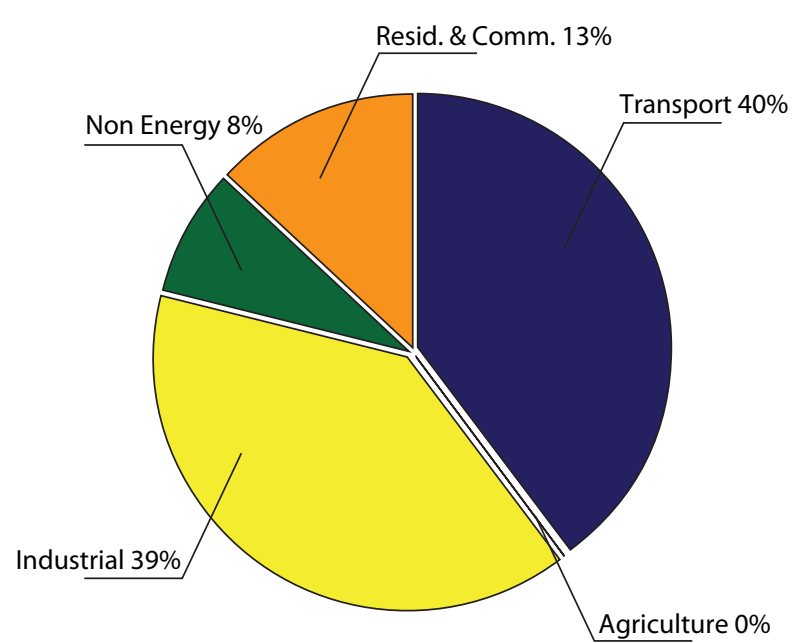

Fig.1. Final energy use by sector

cy for many nations today. This is also the main reason for the Malaysian government to focus extensively and allocate adequate resources in the $9^{\text {th }}$ Malaysian Plan to encourage the efficient use of energy resources and to diversify fuel use in the transport sector. A growing number of passenger and vehicle operating time along with an increase in trip lengths result in a rise of the energy used for propulsion of vehicles. Along with an increase in income levels and the unconstrained expansion of cities, private vehicle population has grown year by year in Malaysia. This affects an increase in energy consumption, especially that from fossil fuels and consequently, increase air pollution due to their combustion. Since the transportation systems are dependent on petroleum oil, which is a scare resource in Malaysia, it is important to plan for energy efficiency in this sector to reduce the rapid use of petroleum oils and growing air pollution, especially $\mathrm{CO}_{2}$ emission. In European Countries, which are mostly oil importers, transportation improvement was achieved by traffic controlled in cities to avoid traffic jams as well as by the implementation of severe rules on vehicle speed on the highway. This had to tremendously reduce the total fuel consumption and maintain air quality (Boardman et al. 2000; Danielis 1995). By implementing several efficiency policies such as a fuel economy program and by introducing alternative fuel cars with lower fuel consumption can lower emissions. Several developed countries such as Japan, England, USA and Sweden have also implemented the policy to reduce energy intensity by population introducing higher taxation for petroleum fuels and penalty for every gram of $\mathrm{CO}_{2}$ emits above the standard level (Grava 2002; Davis and Diegel 2003). Malaysia having the rapid growth of petroleum based fuel consumption tries to introduce Natural Gas to be primary fuel ( $\mathrm{Na}-$ tional Energy Balance 2003). However, it is more challenging for the Malaysian government to implement energy security or reduce energy intensity, especially in terms of petroleum fuels used in the transport sector. The final consumption of petroleum is shown in Fig. 2 (National Energy Balance 2003).

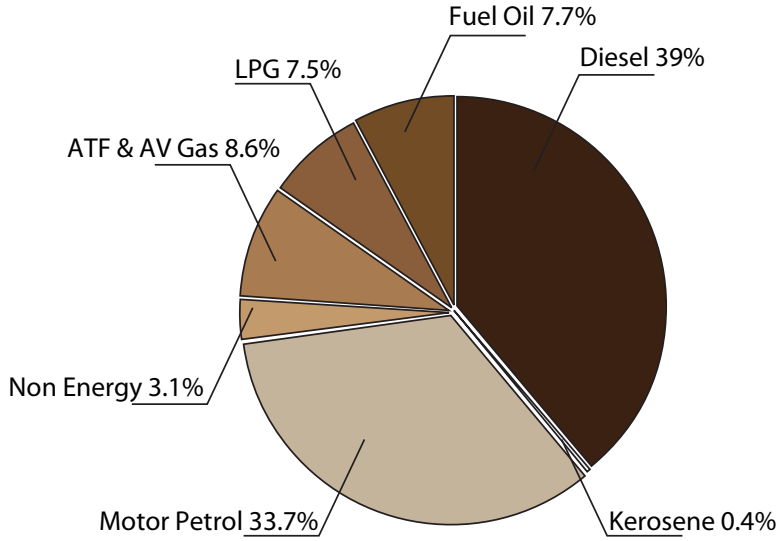

Fig. 2. The final consumption of petroleum products

Energy policies and energy technology make a pair which therefore equally and simultaneously works together. The technologies continually remove the less efficient product from the market and energy policies create transformations in the market. As consumers become energy conscious, manufacturers use efficiency as a marketing tool to win their competition in the market. While combining suitable policies and technologies, Malaysia will be able to promote a more efficient energy used product and will begin important market transformation for the product in the country (Mahlia et al. 2002). It is expected that energy efficiency initiatives for the transportation sector can indeed be tapped and expanded in Malaysia to decelerate the growth of energy consumption in the transportation sector resulting in monetary savings and reduction in the environmental impact (The Malaysian Economic... 2004).

\section{Energy Consumption in Malaysian Transportation Sector}

Over the past decades, it has been observed that there is an increasing atmospheric concentration of greenhouse gases such as carbon dioxide $\left(\mathrm{CO}_{2}\right)$, sulfur dioxide $\left(\mathrm{SO}_{2}\right)$, nitrogen oxide $\left(\mathrm{NO}_{\mathrm{x}}\right)$, carbon monoxide $(\mathrm{CO})$ etc. that have a negative impact on the environment (Danielis 1995). Fig. 3 shows a trend towards transport sector $\mathrm{CO}_{2}$ emissions in 6 Asian countries responsible for more than $95 \%$ of the total $\mathrm{CO}_{2}$ emissions (International Energy Agency... 2007; Timilsina and Shrestha 2009). Aggregate transport sector $\mathrm{CO}_{2}$ emissions at the regional level more than tripled from 210 million tons in 1980 to 745 million tons in 2005 with a robust average annual growth rate of $5.2 \%$. Despite an increase in transport sector emissions in absolute terms, the national total share of the sector in China and India are significantly smaller than that in most Asian countries.

Table 1 shows the total national $\mathrm{CO}_{2}$ emissions and the sectoral emission mix for the above-mentioned 6 Asian countries (International Energy Agency... 2007).

The transport sector shares of the total national $\mathrm{CO}_{2}$ emissions have increased in the Republic of Korea, India and Indonesia and remained more or less stable in China, Malaysia, and Thailand. Because the sectors of 


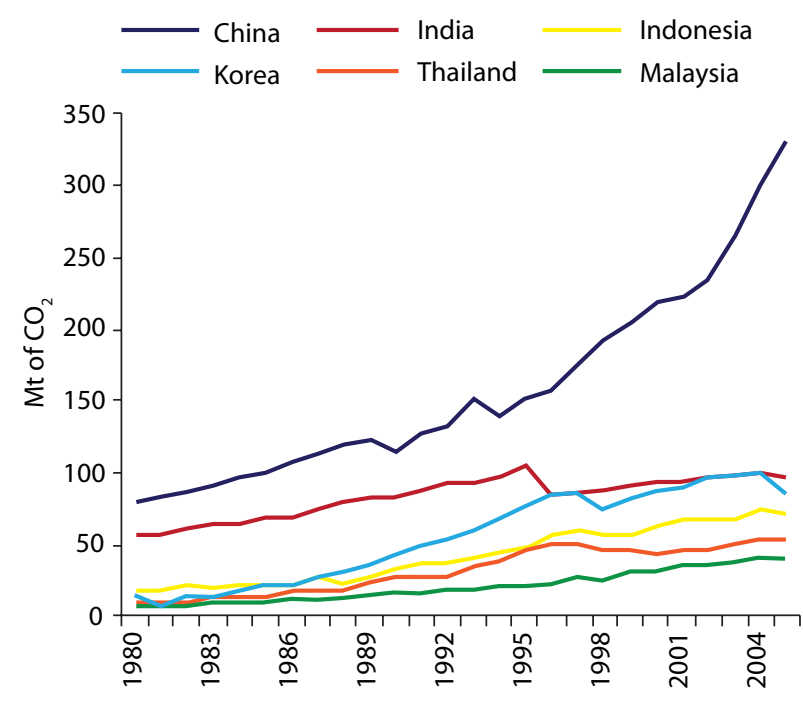

Fig. 3. Trend of transport sector $\mathrm{CO}_{2}$ emissions in Asia

Table 1. The mix of $\mathrm{CO}_{2}$ emissions by sector

\begin{tabular}{|c|c|c|c|c|c|c|c|c|}
\hline \multirow[t]{2}{*}{ Country } & \multicolumn{4}{|c|}{1980} & \multicolumn{4}{|c|}{2005} \\
\hline & $\frac{0_{0}^{N}}{\frac{\pi}{0}}$ & 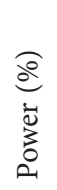 & 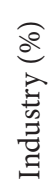 & 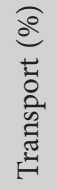 & 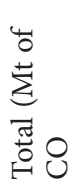 & 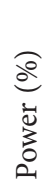 & 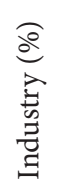 & 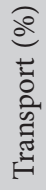 \\
\hline Malaysia & 23 & 32 & 34 & 12 & 449 & 35 & 31 & 19 \\
\hline China & 1403 & 20 & 51 & 6 & 5060 & 48 & 37 & 7 \\
\hline India & 292 & 26 & 39 & 19 & 1147 & 52 & 30 & 8 \\
\hline Indonesia & 69 & 10 & 39 & 26 & 341 & 28 & 39 & 22 \\
\hline Korea & 122 & 20 & 32 & 12 & 449 & 35 & 31 & 19 \\
\hline Thailand & 34 & 33 & 23 & 28 & 214 & 30 & 37 & 26 \\
\hline
\end{tabular}

transport, power and industry are the main contributors to national $\mathrm{CO}_{2}$ emissions, changes in the magnitude of the emissions from other two sectors, particularly the power sector, have a considerable impact on the share of national $\mathrm{CO}_{2}$ emissions in the transport sector.

One of the main contributors of these gases is generated by the transportation sector because a conventional vehicle still uses fossil fuels as their main energy sources. Table 2 shows the final energy use by the transportation sector in Malaysia (Boardman et al. 2000; National Energy Balance 2005).

The types of fossil fuels used in the transportation sector in Malaysia include natural gas, Aviation gasoline (Avgas), Motor gasoline (Mogas) and Aviation Turbine Fuel (ATF or Avtur). Diesel oil and fuel oil Natural Gas fuel make a mixture of gaseous hydrocarbons (mainly methane) which occur either in gas fields or in association with crude oil in oil fields. The use of energy in the transportation sector based on fuel types is given in Table 3 (National Energy Balance 2005).
Table 2. Final energy use by the transportation sector

\begin{tabular}{cc}
\hline Year & Total (ktoe) \\
\hline 1980 & 2398 \\
\hline 1985 & 3477 \\
\hline 1990 & 5387 \\
\hline 1995 & 7827 \\
\hline 1996 & 8951 \\
\hline 1997 & 10201 \\
\hline 1998 & 9793 \\
\hline 1999 & 11393 \\
\hline 2000 & 12071 \\
\hline 2001 & 13137 \\
\hline 2002 & 13442 \\
\hline 2003 & 13532 \\
\hline 2004 & 13721 \\
\hline 2005 & 14062 \\
\hline
\end{tabular}

Table 3. Energy structure according to fuel types used in the transportation sector in Malaysia

\begin{tabular}{ccccccc}
\hline \multirow{2}{*}{ Year } & \multicolumn{5}{c}{ Fuel type (ktoe) } \\
\cline { 2 - 7 } & Petrol & Diesel & ATF & Fuel oil & NG & Elect \\
\hline 1980 & 1296 & 847 & 250 & - & 0 & 0 \\
\hline 1985 & 2057 & 1032 & 386 & - & 0 & 0 \\
\hline 1990 & 2889 & 1826 & 628 & 41 & 0 & 0 \\
\hline 1995 & 4477 & 2168 & 1158 & 17 & 5 & 0 \\
\hline 1996 & 5161 & 2417 & 1333 & 32 & 4 & 1 \\
\hline 1997 & 5574 & 3106 & 1437 & 75 & 5 & 1 \\
\hline 1998 & 5849 & 2311 & 1618 & 9 & 4 & 1 \\
\hline 1999 & 6778 & 3174 & 1423 & 13 & 0 & 4 \\
\hline 2000 & 6378 & 4103 & 1574 & 4 & 7 & 4 \\
\hline 2001 & 6820 & 4534 & 1762 & 5 & 14 & 5.17 \\
\hline 2002 & 6940 & 4680 & 1785 & 5.5 & 28 & 5.20 \\
\hline 2003 & 7120 & 4732 & 1798 & 5.8 & 36 & 5.5 \\
\hline 2004 & 7531 & 4791 & 1815 & 6 & 44 & 6 \\
\hline 2005 & 7865 & 4812 & 1830 & 6.5 & 56 & 6.2 \\
\hline & & & & & & \\
\hline
\end{tabular}

The summation of the total energy use in Table 3 is not very similar to the data provided in Table 4 because there are some other types of fuel that are not included in Table 3 and comprise LPG and Avgas that have been used for transport fuel. Time series data for such types of fuels is also unavailable and difficult to predict. Vehicle-kilometer or passenger-kilometer is the key point in estimating energy consumed in the transportation sector. Table 4 shows energy use by various types of vehicles based on passenger travel distance (Norhayati and Yuslina 2001; Grava 2002; Davis and Diegel 2002). 
Table 4. Energy use by various types of vehicles

\begin{tabular}{ccc}
\hline No. & Vehicle type & $\begin{array}{c}\text { Energy use } \\
\text { (btu/passenger mile) }\end{array}$ \\
\hline 1 & $\begin{array}{c}\text { Single-occupancy } \\
\text { automobile }\end{array}$ & 8360 \\
\hline 2 & New heavy rail & 3080 \\
\hline 3 & Carpool & 2390 \\
\hline 4 & Old heavy rail (existing) & 2320 \\
\hline 5 & Light rail transit & 2590 \\
\hline 6 & Bus & 1420 \\
\hline 7 & Aircraft & 3666 \\
\hline
\end{tabular}

\section{Modes of Transportation}

The transportation system is often analyzed in terms of various modes of transportation. Although it is very commonly used, the term mode does not have a clear definition. In general, it means a 'kind' of transportation. The modes are sometimes classified as road, rail, maritime and air transport. Table 5 indicates the modes in the transport sector (Banks 2001). Road transport classification in Malaysia involves several types of vehicles such as a motorcar, motorcycle, bus, commercial vehicle and other vehicles. For modal split purposes, the vehicles are also classified into private and public service vehicles.

Table 5. Mode classification scheme

\begin{tabular}{ccc}
\hline Descriptions & Freight & Passenger \\
\hline Urban & Truck (highway) & $\begin{array}{c}\text { Private auto(highway) } \\
\text { Transit (highway/rail) }\end{array}$ \\
\hline & $\begin{array}{c}\text { Truck (highway) } \\
\text { Rail ocean } \\
\text { Shipping inland } \\
\text { Water air pipeline }\end{array}$ & $\begin{array}{c}\text { Private auto(highway) } \\
\text { Bus (highway) } \\
\text { Rail air }\end{array}$ \\
\hline $\begin{array}{c}\text { Special } \\
\text { purpose }\end{array}$ & $\begin{array}{c}\text { Conveyor belt } \\
\text { Cable systems }\end{array}$ & \\
\hline
\end{tabular}

\section{Motorcars and Motorization}

As depicted in Table 6 (Time Series Data... 2006), the numbers of motorcars increase significantly every year. The annual growth of motorcar population from 1991 to 2008 makes about $9.53 \%$ while for motorization it is $6.78 \%$. If compared to the annual growth rate of population, an increase in motorcar ownership is relatively higher. As illustrated in Table 6, if compared to the motorization rates of motorcars, the motorization rates of motorcycles seem relatively higher. However, the annual rate of an increase in motorcycles is lower than that in motorcars (only $4.95 \%$ per year). On the other hand, the population of motorcycles is higher than that of motorcars.
Table 6. The number of motorcars in Malaysia

\begin{tabular}{cccc}
\hline \multirow{2}{*}{ Year } & \multirow{2}{*}{ Population } & \multicolumn{2}{c}{ Motorcars } \\
\cline { 3 - 4 } & & Number & Motorization level \\
\hline 1991 & 18.547 & 1863.2 & 100 \\
\hline 1992 & 19.43 & 1983.0 & 104 \\
\hline 1993 & 19.564 & 2132.3 & 109 \\
\hline 1994 & 20.112 & 2350.1 & 117 \\
\hline 1995 & 20.689 & 2608.6 & 126 \\
\hline 1996 & 21.169 & 2946.0 & 139 \\
\hline 1997 & 21.666 & 3333.4 & 154 \\
\hline 1998 & 22.180 & 3517.5 & 159 \\
\hline 2000 & 22.712 & 3852.7 & 170 \\
\hline 2002 & 23.275 & 4212.6 & 181 \\
\hline 2004 & 24.012 & 4624.6 & 193 \\
\hline 2006 & 24.527 & 5069.4 & 207 \\
\hline
\end{tabular}

\section{Air Quality Policies}

In addition to carbon dioxide, vehicle usage results in other gas emissions, many of which have implications for local air quality. Three of these are covered by the Euro standards and include carbon monoxide, hydrocarbons and nitrogen oxides. All are measured separately for petrol and diesel cars. Particulate matter for diesel cars only is tabulated in Table 2. Diesel produces about $15 \%$ more $\mathrm{CO}_{2}$ per liter than petrol but diesel engines on the whole produce less $\mathrm{CO}_{2}$ per km because the diesel engine is inherently more efficient than the petrol one (Myint 2001).

At the same time, diesel-engine vehicles emit around ten times more mass fine particles and up to two times nitrogen oxides in comparison to petrol-fuelled vehicles. Policy needs, therefore to be a balanced one, to reflect the impacts of both changes in local air quality and changes in global climate recognizing that fuels have different benefits and disadvantages (Liaskas et al. 2000; Dhakal 2003). In Europe, the Directive is a part of a trio of policy approaches concerned with climate change. These include a voluntary agreement to reduce emissions suggesting technical improvements to new cars and fiscal measures. In the UK, such measures include differentiated vehicle excise duty related to carbon dioxide emissions and reduced company car allowances. There are several things to be done in the transport sector in order to put a brake on the drift consumption by modern society (Time Series Data... 2006; Barbusse 2001):

- introducing beneficial tax systems to promote the purchase of more economical vehicles using clean fuel;

- opening public procurement to clean vehicles so that governments and administrations should buy a certain amount of these vehicles creating a market for them and persuading manufacturers to produce them on a large scale; 
- limiting the fuel consumption of vehicles and prompting car industry to further increase the energy performance of cars;

- improving traffic management with the help of multiple applications and services available from 2008 under the European satellite radio navigation programme GALILEO providing a possibility of smoothing the flow of traffic;

- organizing the management of air traffic so as to reduce an increase in congestion and kerosene waste near airports.

\section{Implementation}

The rising price of petrol throughout the world has a direct impact on transportation costs that are eventually borne by consumers. Thus, energy efficiency initiatives focus on public transport targets such as improved vehicle efficiency and emerging renewable fuel technologies. Based on findings, some recommendation regarding to energy use in the transportation sector could be suggested. Currently, there are several transportation programmers viable for Malaysia:

- The increased use of public transport. Large urban centres (Klang Valley, Penang and Johor Bahru) can maximize energy saving potential by increasing public transport to $50 \%$ by 2020 , thus minimizing urban congestion, air pollution and safety problems and significantly lowering fuel consumption attributed to rapidly growing car population.

- The development of Intelligent Transport Information Systems (ITIS). Improving traffic flows with proper road network capacity along with better traffic management (signal operation, ramp metering etc.) can reduce problems related to urban congestion. Such actions may include the use of INSIAX or SMART.

- The increased use of alternative fuel technologies. As outlined by the National Biofuel Policy, biofuels help with diversifying fuel consumption by introducing alternative renewable options. By utilizing blends of bio-diesel and bio-ethanol together with natural gas, these new fuel technologies allow greater savings in fuel consumption.

- Strategic improvement in vehicle efficiency. Aimed at improving fuel efficiency for the entire vehicle fleet, these measures are geared towards establishing higher standards and promoting technologies to offset rising petrol prices. In addition to fuel cost savings, a move to lighten road load will lessen strain on the supply of transport fuels.

\section{Conclusions}

Besides policies on motor vehicles, there are not many worldwide used procedures that have been implemented for reducing energy use in the transport sector. This is due to the fact that technology replacement for airplane and ship is not that progressive as for a motor vehicle.
Similar replacement for railway was brought in Japan and France; however replacement was not really related to energy but more to the increasing speed of mass railway transport. Therefore, the study is more favored to motor vehicles since they are the major energy consumers in the transportation sector in this country. Several countries find the opportunity to experiment with innovative approaches that go considerably beyond this minimum level. This is in order to reduce contribution that new cars are making to environmental degradation and climate change. The focus on fuel economy provides substantial benefits to consumers, particularly when rising real oil prices and concerns about the cost of petrol. Overall, dependency on petrol fuel could be reduced and greenhouse gas emission could be mitigated. Additionally, fuel subsidy on petrol and diesel given by the Government in the future should be withdrawn; consumers will not pay more for efficient vehicles unless its effectiveness is approved, whereas it shows the benefit of using a lesser amount of fuel due to the increasing cost of the fuel.

\section{Acknowledgment}

The authors wish to thank Universiti Sains Malaysia for providing the USM fellowship scheme.

\section{References}

Banks, J. H. 2001. Introduction to Transportation Engineering. 3 edition. McGraw Hill Higher Education.

Barbusse, S. 2001. Motorcycles, mopeds: polluting emissions and energy consumption - Initial observations. Agence de l'Environnement et de la Maître de l'Energie, Département Technologies des Transport, France, May 2001.

Boardman, B.; Banks, N.; Kirby, H. R.; Keay-Bright, S.; Hutton, B. J.; Stradling, S. G. 2000. Choosing cleaner cars: the role of labels and guides. Final Report on a Research Study on Vehicle Environmental Rating Schemes. TRI Record 00/10/02. Transport Research Institute, Napier University, Edinburgh. 159 p. Available from Internet: <http://www. eci.ox.ac.uk/research/energy/downloads/cleanercars.pdf $>$.

Danielis, R. 1995. Energy use for transport in Italy: Past trends, Energy Policy 23(9): 799-807. doi:10.1016/0301-4215(95)00059-R

Davis, S. C.; Diegel, S. W. 2003. Transportation Energy Data Book: Edition 23. Center for Transportation Analysis Engineering Science \& Technology Division. 354 p. Available from Internet: <http://www.osti.gov/bridge/servlets/ purl/885559-hjrVfl/885559.pdf>. doi:10.2172/885559

Davis, S. C.; Diegel, S. W. 2002. Transportation Energy Data Book: Edition 22. Center for Transportation Analysis Engineering Science \& Technology Division. 352 p. Available from Internet: <http://www-cta.ornl.gov/cta/Publications/ Reports/ORNL-6967.pdf>.

Dhakal, S. 2003. Implications of transportation policies on energy and environment in Kathmandu Valley, Nepal, Energy Policy 31(14): 1493-1507. doi:10.1016/S0301-4215(02)00205-7

Grava, S. 2002. Urban Transportation System: Choices for Communities. 1 edition. McGraw-Hill Professional. 840 p.

International Energy Agency (IEA) Textbase. 2007. Release 01: $\mathrm{CO}_{2}$ Emissions from Fuel Combustion. Available from Internet: <http://www.iea.org $>$. 
Liaskas, K.; Mavrotas, G.; Mandaraka, M.; Diakoulaki, D. 2000. Decomposition of industrial $\mathrm{CO}_{2}$ emissions: The case of European Union, Energy Economics 22(4): 383-394. doi:10.1016/S0140-9883(99)00035-3

Mahlia, T. M. I.; Masjuki, H. H.; Choudhury, I. A. 2002. Development of energy labels for room air conditioner in Malaysia: methodology and results, Energy Conversion and Management 43(15): 1985-1997. doi:10.1016/S0196-8904(01)00145-5

Malaysia Initial National Communication. 2000. Ministry of Science, Technology and Environment (MOSTE). 131 p. Available from Internet: <http://www.bdix.net/sdnbd_org/ nationa_communication_not_in_annex1/Malaysia_1.pdf $>$.

Myint, S. 2001. Transport energy use and vehicle emissions in Myanmar, ASEAN Energy Bulletin 5(1). ASEAN Centre for Energy, Jakarta.

National Energy Balance. 2003. Ministry of Energy Communications and Multimedia, Kuala Lumpur, Malaysia.

National Energy Balance. 2005. Ministry of Energy Communications and Multimedia, Kuala Lumpur, Malaysia.

Norhayati, K.; Yuslina, M. Y. 2001. Vehicle emissions, measures and challenges in Malaysia road transportation sector, ASEAN Energy Bulletin 5(1). ASEAN Centre for Energy, Jakarta.

The Malaysian Economic in Figures. 2004. Economic Planning Unit. Prime Minister's Department, Putrajaya, Malaysia. Available from Internet: <http://www.epu.gov.my>.

Time Series Data, Malaysia. 2006. Website of Department of Statistics Malaysia. Available from Internet: <http://www. statistics.gov.my>.

Timilsina, G. R.; Shrestha, A. 2009. Transport sector $\mathrm{CO}_{2}$ emissions growth in Asia: Underlying factors and policy options, Energy Policy 37(11): 4523-4539.

doi:10.1016/j.enpol.2009.06.009 